\title{
Gastrin and the growth of the gastrointestinal
}

\section{tract}

\author{
A A Ekundayo, C Y Lee, R A Goodlad
}

trophic role of gastrin is restricted to the gastric fundus and the proximal duodenum.

(Gut 1995; 36: 203-208)

Keywords: cell division, gastrin, growth control.

The gastrointestinal tract is a multilayered defence and absorption system, whose maintenance depends on a process of continual cell renewal. Enhanced rates of proliferation are, nevertheless, implicated in the pathophysiology of gastrointestinal carcinogenesis and can act as a promoter of, and can even be considered to be a cause of carcinogenesis. ${ }^{1}$ Intestinal cell proliferation is controlled by a variety of luminal and systemic influences. ${ }^{2}$ One gastrointestinal hormone with a well recorded proliferative role in the stomach is gastrin. ${ }^{3-7}$

Nevertheless, there is a considerable degree of confusion regarding the role of gastrin on the growth of the other regions of the gastrointestinal tract. Johnson ${ }^{89}$ reported that gastrin has a general trophic role throughout the gastrointestinal tract, which led to a spate of publications challenging this. ${ }^{10} 111^{12-15}$ Some of the discrepancies in published works could be partly attributed to the use of inappropriate techniques to measure cell proliferation, particularly the use of gross tritiated thymidine uptake in mucosal scrapings in vitro. ${ }^{16}{ }^{17}$ Some studies using more reasonable methods to study proliferation in hamsters with changed endogenous gastrin concentrations, however, also showed trophic effects on the (fasted) colon. ${ }^{18}$ An alternative explanation for these discrepancies is that pentagastrin or gastrin are only trophic to the fasted colon, not to the fed colon. ${ }^{1920}$

A role for gastrin in the control of colonic cell renewal has recently been indicated by the finding that gastrin can stimulate the growth of several colon cell lines and carcinomas. ${ }^{21}$ Furthermore, postprandial gastrin concentrations may be higher in colon cancer patients, ${ }^{22}$ and recent results show that longlasting endogenous hypergastrinaemia is accompanied by increased in vivo cell proliferation in the human colonic mucosa. The prevalence of adenomas does not seem to be different in hypergastrinaemia, however, from that of the general population. ${ }^{23}$

Recent interest in the effects of, and potential risks of, increased gastrin concentrations has been rekindled by the longterm increase in plasma gastrin concentrations accompanying the introduction, and use of, very effective inhibitors of gastric acid

Figure 1: The effects of pentagastrin (PG) and gastrin 17 on gastric $p H . A O V O=$ one way analysis of variance for the TPN control group and the three doses of pentagastrin. $\star=$ Significantly different (by t test) to the TPN control group $(p<0.01)$. 


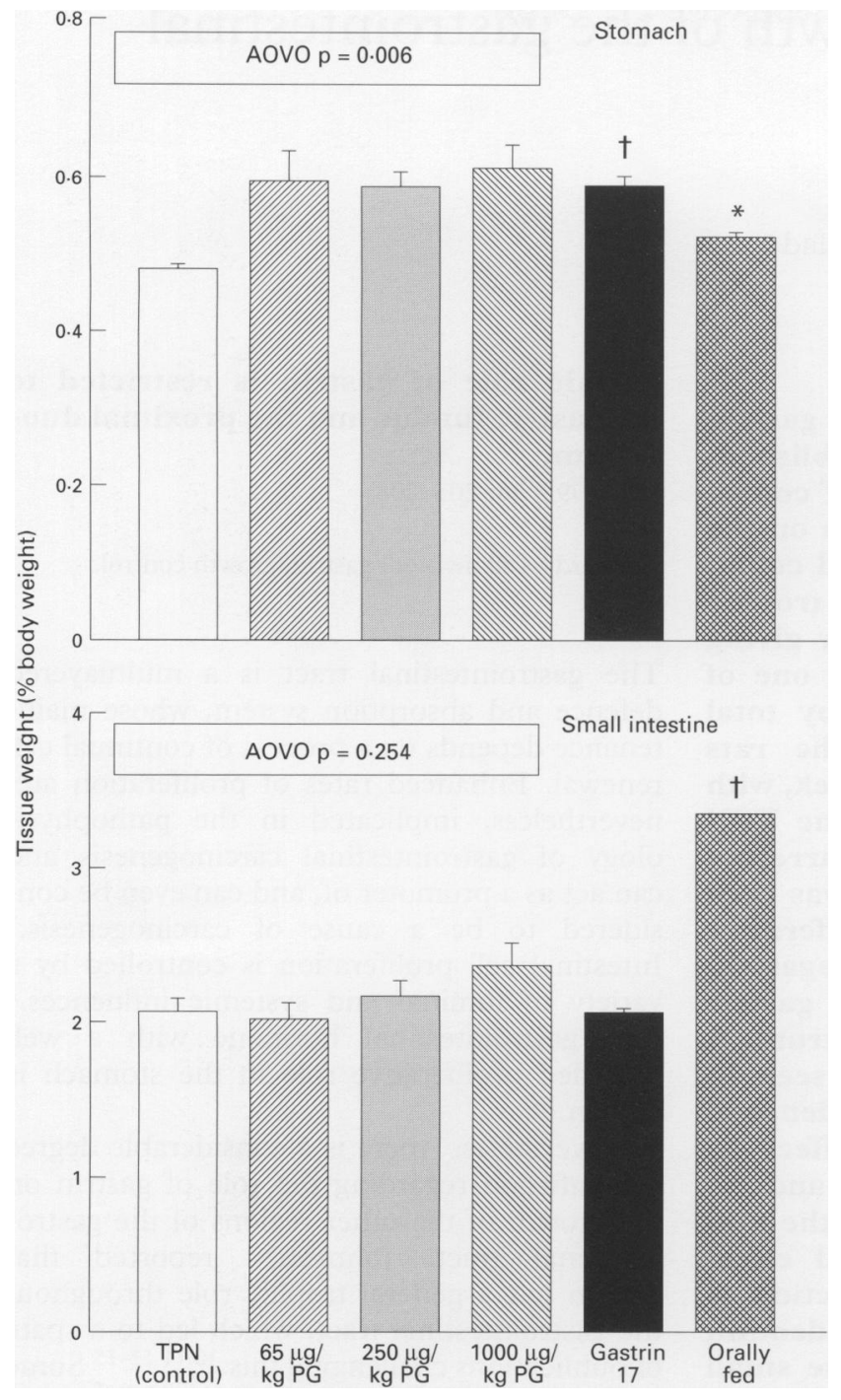

Figure 2: The effects of the various treatments on gastric and intestinal wet weight (expressed as a percentage of total body weight). AOVO=one way analysis of variance for the TPN control group and the three doses of pentagastrin. ${ }^{\star}=$ Significantly different to the TPN control group $(p<0.01) ; \dagger=$ significantly different to the TPN control group $(p<0.001)$.

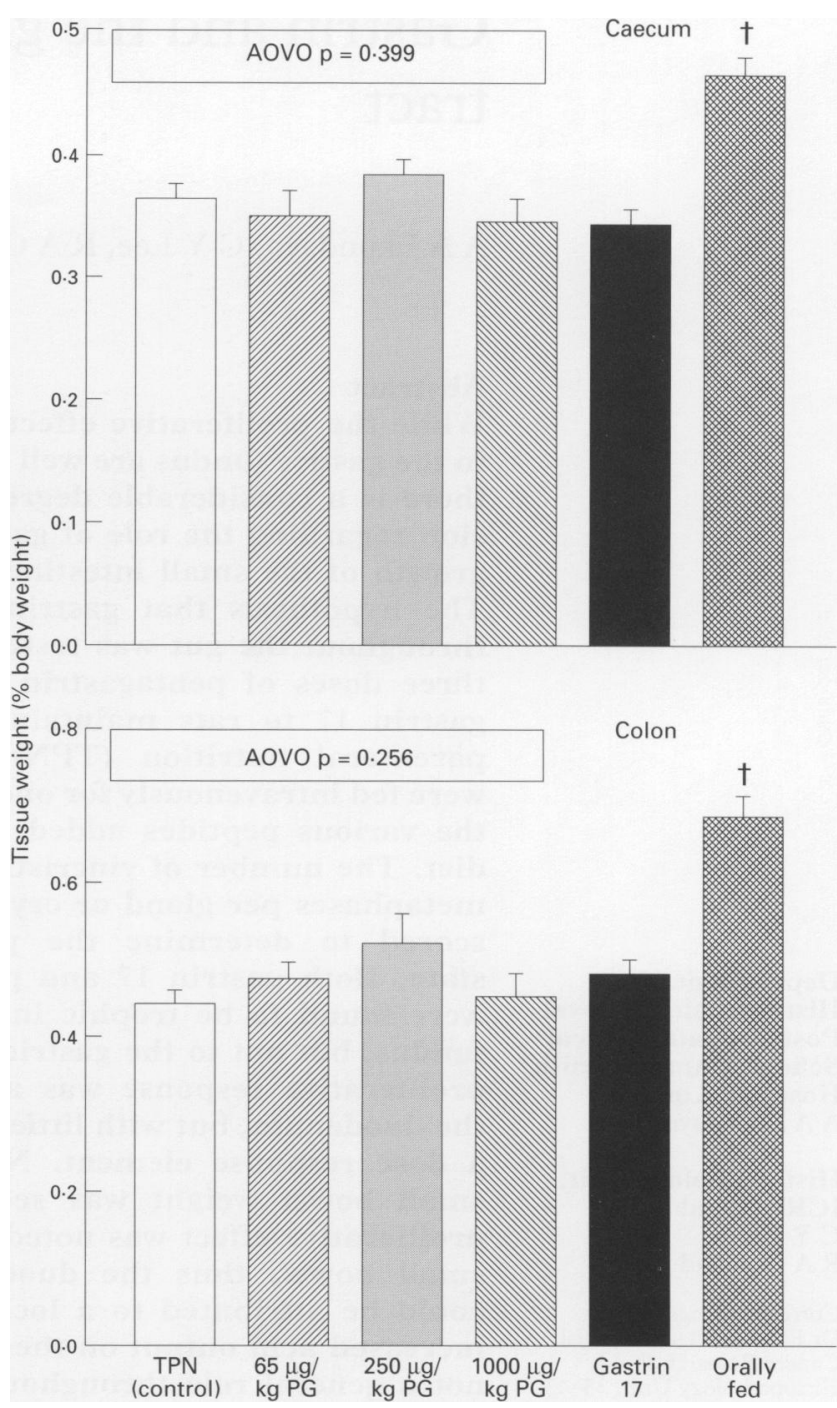

Figure 3: The effects of the various treatments on caecal and colonic wet weight (expressed as a percentage of total body weight). AOVO=one way analysis of variance for the TPN control group and the three doses of pentagastrin. $\dagger=$ significantly different to the TPN control group $(p<0.001)$. secretion. This study was designed to test the hypothesis that gastrin is trophic throughout the gut, and used the 'starved' gut of the total parenteral nutrition (TPN) rat, where the lack of luminal contents, reduced endogenous secretions, and lowered plasma hormone concentrations should make any effects of exogenous peptides more discernible. ${ }^{17}$

\section{Methods}

\section{EXPERIMENTAL DESIGN}

Five groups of six rats were infused with $60 \mathrm{ml} / \mathrm{rat} /$ day of a TPN diet for six days. The first group (control) was infused with the basic TPN diet. The second group of six rats were given $65 \mu \mathrm{g} / \mathrm{kg} /$ day of pentagastrin (ICI Pharmaceuticals, Macclesfield, Cheshire, England) in the TPN diet. The third and fourth groups of six rats each were given $250 \mu \mathrm{g} / \mathrm{kg}$ and $1000 \mu \mathrm{g} / \mathrm{kg} /$ day of pentagastrin respectively. The fifth group was given $107 \mu \mathrm{g} / \mathrm{kg}$ of rat gastrin 17 (Bachem,
Saffron Walden, Essex), which is the predominant form of gastrin. ${ }^{24}$ The sixth group of rats were orally fed throughout the experiment.

\section{ANIMALS}

Male Wistar rats, weighing between $180-200 \mathrm{~g}$ were used. They were housed in rooms with a 14:10 hour light:dark cycle. TPN rats were anaesthetised with $0.06 \mathrm{ml}$ Hypnorm (Janssen Pharmaceuticals, Grove, Oxford) and $0.06 \mathrm{ml}$ diazepam, and a silastic cannula tied into the right external jugular vein. The cannula was tunnelled subcutaneously to the back of the neck and then taken through a stainless steel skin button and tether to a fluid swivel joint (SMA, Barnet, England). The TPN diets were kept at $4^{\circ} \mathrm{C}$ and pumped into the rats by a multichannel peristaltic pump, at a rate of $60 \mathrm{ml} / \mathrm{rat} /$ day giving $1.8 \mathrm{~g} \mathrm{~N}, 6.0 \mathrm{~g}$ lipid, $8.5 \mathrm{~g}$ glucose, and $1047 \mathrm{~kJ}$ per $\mathrm{kg}$ per day ${ }^{25}$ and each bag comprised of $2000 \mathrm{ml}$ of the amino acid, electrolyte, and glucose solution, vamin 9 glucose (KabiVitrum, Uxbridge, Middlesex), 


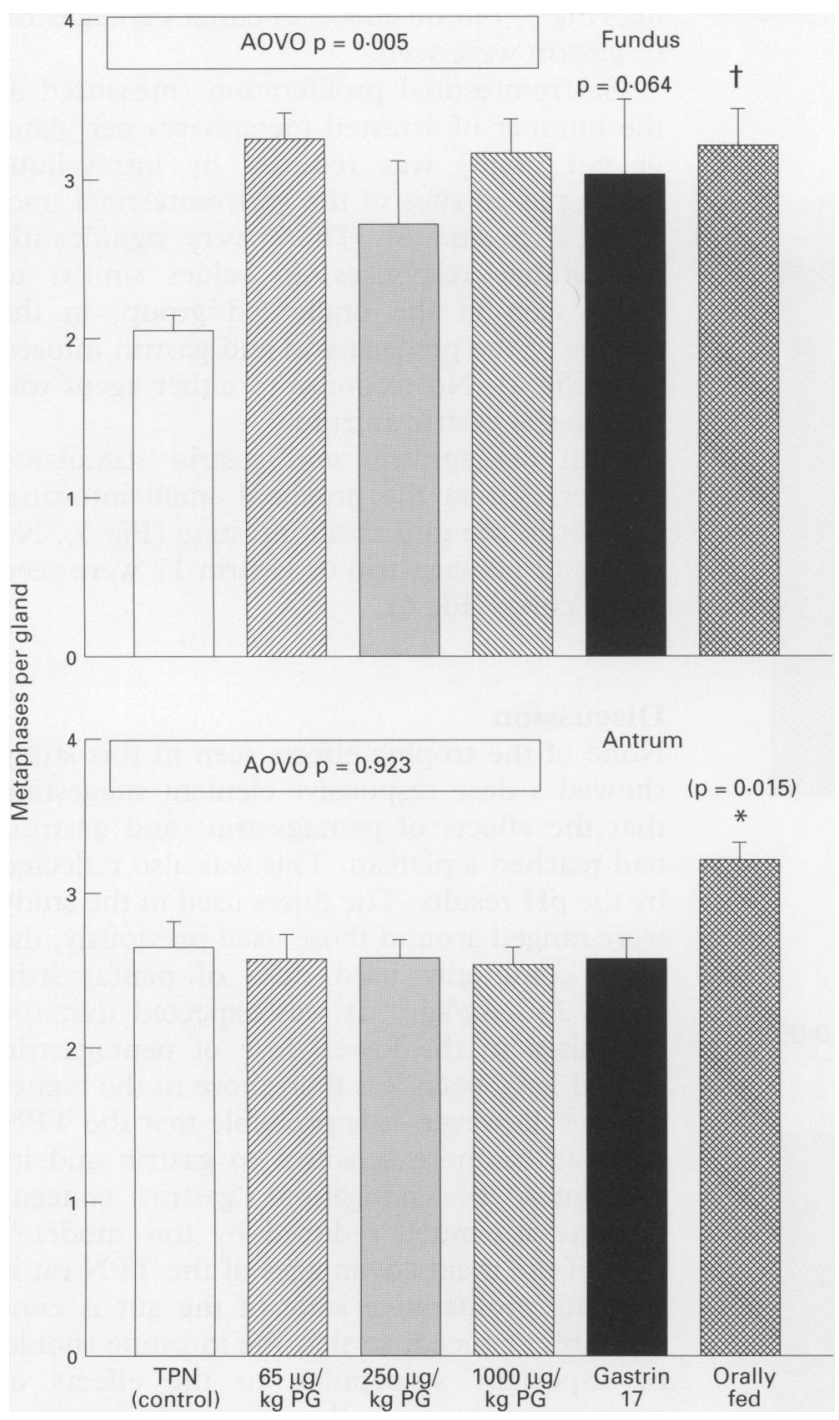

Figure 4: The effects of the various treatments on the number of vincristine arrested metaphases per gastric gland. AOVO=one way analysis of variance for the TPN control group and the three doses of pentagastrin. * = Significantly different to the TPN control group $(p<0.05)$; $\dagger=$ significantly different to the TPN control group $(p<0.01)$.

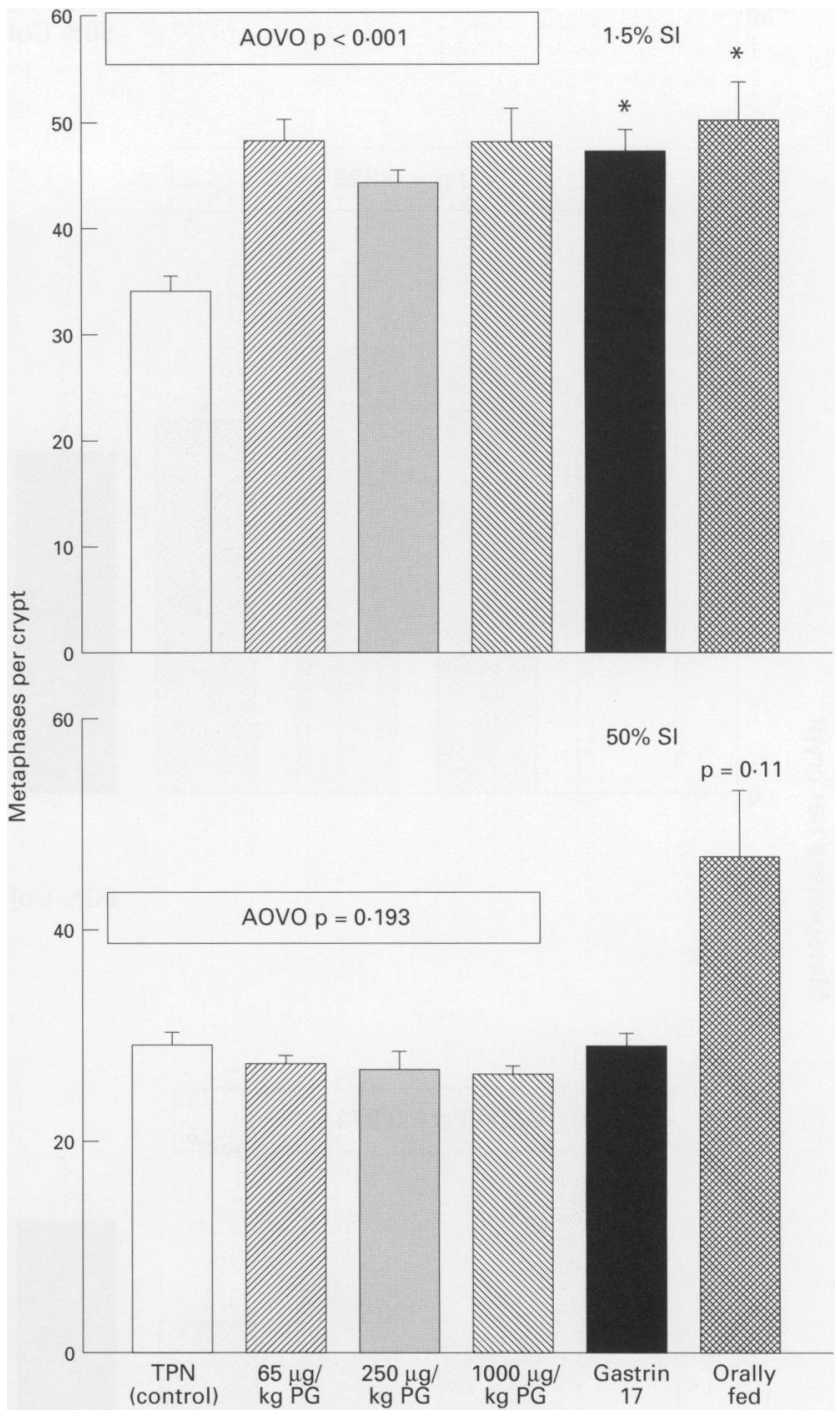

Figure 5: The effects of the various treatments on the number of vincristine arrested metaphases per intestinal crypt. $1.5 \% S I=1.5 \%$ of the length of the small intestine (duodenum) $50 \%$ SI $=50 \%$ of the length of the small intestine. AOVO=one way analysis of variance for the (TPN control and pentagastrin). ${ }^{\star}=$ Significantly different to the TPN control group $(p<0 \cdot 01)$.
$400 \mathrm{ml} 50 \%$ dextrose, $250 \mathrm{ml} 20 \%$ intralipid (KabiVitrum), and $146 \mathrm{ml}$ of an electrolyte and vitamin mixture, giving an energy content of $0.95 \mathrm{kcal} / \mathrm{ml}$.

The orally fed rats were given Labshure PRD (Labshure, Poole, Dorset) ad libitum (composition barley, oats, wheat, wheatfeed, maize meal, soybean extracts, dried skim milk, Torula yeast, white fish meal, minerals and vitamins (crude protein 198, crude oil 27, carbohydrate 538 , crude fibre $53(\mathrm{~g} / \mathrm{kg})$ ).

The rats received the different treatments for six days and were then injected with vincristine sulphate, $1 \mathrm{mg} / \mathrm{kg}$, intraperitoneally (David Bull Laboratories, Warwick), anaesthetised two hours later with pentobarbitone, and then exsanguinated. All rats were killed between 1100 to 1300 . The wet weight of the various sections of the gastrointestinal tract was recorded and samples of the small intestine and colon were fixed in Carnoy's fluid and stored in $70 \%$ ( $\mathrm{vol} / \mathrm{vol}$ ) ethanol. The $\mathrm{pH}$ of the gastric contents was measured using narrow range $\mathrm{pH}$ paper (pH 1-4, Whatman, Maidstone, Kent). Tissue was stained later with the Feulgen reaction and the crypts displayed by microdissection. ${ }^{16}$ The numbers of arrested metaphases in 20 gastric glands or intestinal crypts were counted and the mean values compared.

\section{STATISTICS}

All the results were presented as mean (SEM).

Data were tested as appropriate by two sided $t$ test or by analysis of variance. When there was a statistically significant result with the one way analysis of variance, individual treatments were analysed by Dunnet's test.

Although the results presented were corrected for body weight changes, no differences in the pattern of results were seen using the gross weight or the corrected weights.

\section{Results}

There were no differences in the end weight of the TPN rats $234(2 \cdot 89) \mathrm{g}$. (The start weight being $221(2 \cdot 75)$ g.) The end weight of the orally fed rats was significantly higher (276 


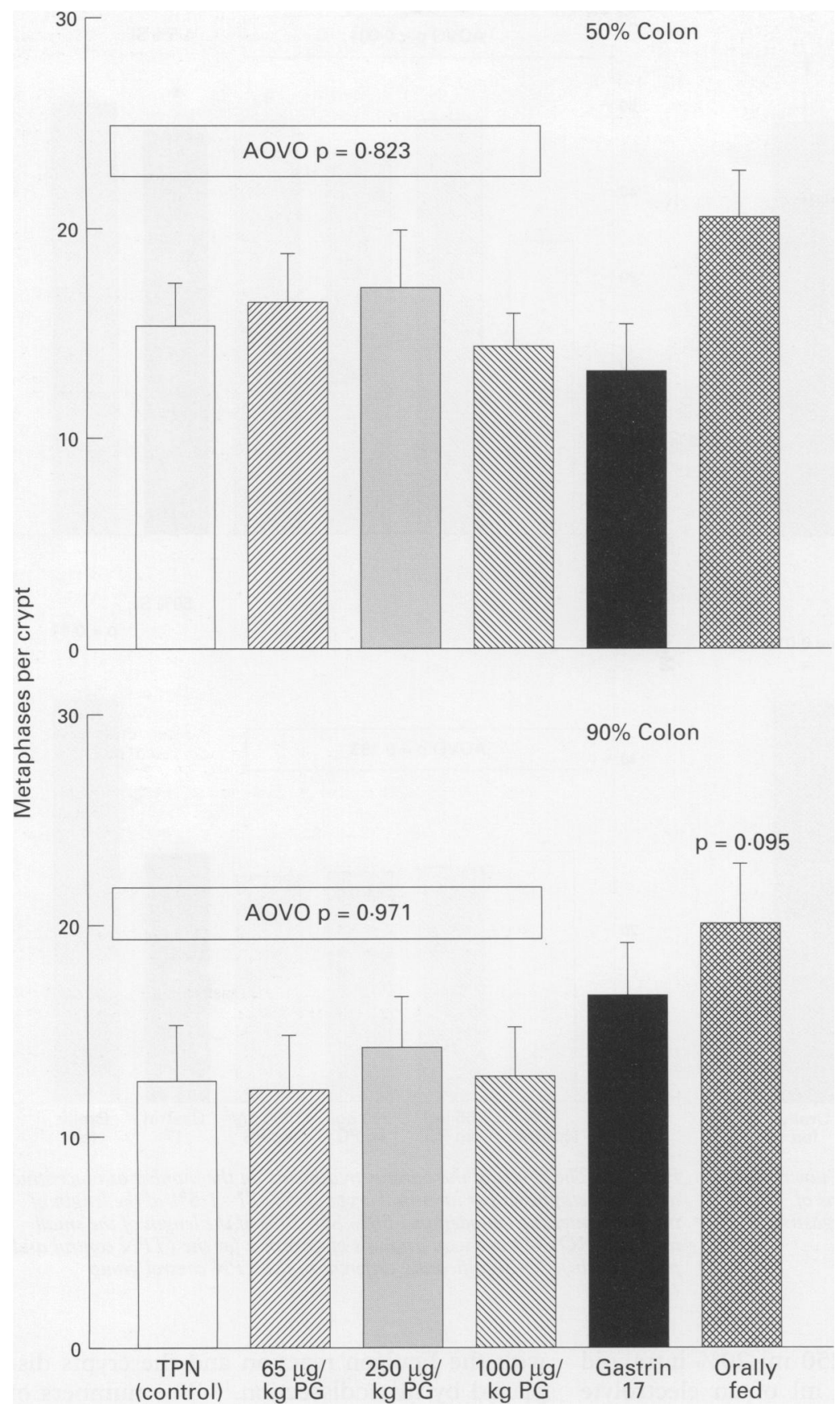

Figure 6: The effects of the various treatments on the number of vincristine arrested metaphases per colonic crypt. $50 \%$ colon $=50 \%$ of the length of the colon $90 \%$ colon $=90 \%$ of the length of the colon. AOVO=one way analysis of variance for the TPN control group and the three doses of pentagastrin. ing (Fig 3) but no effects of either pentagastrin or gastrin were seen.

Gastrointestinal proliferation (measured as the number of arrested metaphases per gland or per crypt) was reduced by intravenous feeding at all sites of the gastrointestinal tract (Figs 4, 5, and 6). There were significantly proliferative responses, to values similar to those seen in the orally fed group, in the fundus of the pentagastrin and gastrin infused rats (Fig 4). No response to either agent was seen in the gastric antrum.

Both pentagastrin and gastrin stimulated proliferation in the proximal small intestine, but not in the mid small intestine (Fig 5). No effects of pentagastrin or gastrin 17 were seen in the colon (Fig 6).

\section{Discussion}

None of the trophic effects seen in this study showed a dose responsive element suggesting that the effects of pentagastrin (and gastrin) had reached a plateau. This was also reflected by the $\mathrm{pH}$ results. The doses used in the study were ranged around those used previously, the most commonly used dose of pentagastrin being $250 \mu \mathrm{g} / \mathrm{kg} .{ }^{20}$ It was expected that the responses to the lower dose of pentagastrin should have been less than those to the higher doses, ${ }^{26}$ however, it is probable that the TPN rat may be more sensitive to gastrin and its analogues, as endogenous gastrin concentrations are much reduced by this model. ${ }^{27}$ One of the main advantages of the TPN rat is that the proliferative state of the gut is considerably reduced, so that the intestine should be especially susceptible to the effects of exogenous factors. In this respect the intestine of the TPN rat should be similar to that of the starved animal. A proliferative effect of pentagastrin on the colon of starved rat was noted by Fatemi et $a l^{28}$ but surprisingly they did not find any effect on the stomach, a site that invariably shows a trophic response to gastrin. These authors used a somewhat unusual measure of proliferation, namely gross tritiated thymidine activity per microdissected crypt/gland. A possible explanation for these dilemmas is provided by the finding that gastrin can induce changes in the activity of thymidine kinase in the colon. ${ }^{29}$ An alternative explanation for the increases in tritiated thymidine uptake associated with gastrin could be that gastrin increased cellular permeability and transport. ${ }^{30}$ These findings lend further weight to our opposition to utilisation of in vivo proliferative measures based on the gross uptake of tritiated thymidine ${ }^{163132}$ as used in the much cited work of Johnson et al. Many of these problems can be avoided if the all or nothing nature of scoring labelled cells in autoradiographs is exploited, or if a metaphase arrest technique is used. Furthermore, many of the confounding factors associated with scoring sections can also be avoided when microdissected crypts are quantified.

The results of this study clearly confirm that the hormone gastrin and its synthetic analogue pentagastrin have important trophic actions on 
the fundus of the stomach, and the proximal small bowel. The lack of effect on the antrum is also well recorded, ${ }^{33-3536}$ and is in agreement with the physiological principle that a tissue should not be stimulated by its own secretions.

There was a considerable proliferative effect of both pentagastrin and gastrin on the proximal, but not on the mid small intestine, which could perhaps be attributed to the irritative effects of the high acid input from the maximally stimulated stomach, as if gastrin was having a systemic effect, proliferation should also have been increased throughout the small intestine. The lack of a more general effect was reflected by the lack of significant change in tissue weight. Increased duodenal proliferation should help protect this particularly vulnerable region of the intestine, as we have shown that inhibition of duodenal proliferation predisposes towards ulceration. ${ }^{37}$

This situation may be further complicated by the infamous Helicobacter pylori, chronic infection with which also increases acid output. $^{38}$

The potential role of gastrin and pentagastrin in the stimulation of growth of colonic cancers has been subjected to considerable investigation. Evidence exists to suggest that the growth of some colonic cancers is stimulated. It has also been shown that exogenous pentagastrin increases the growth rate of certain human colon cancer cell lines maintained as xenografts. ${ }^{39} 40$ Similar effects have been reported for chemically induced colonic tumours in rats ${ }^{41}$ and gastrin antagonists can reduce these trophic effects. ${ }^{21}$ Not all groups have found these effects, ${ }^{42}$ however, and no effect of gastrin was seen on colon explants. ${ }^{43}$

A trophic role for gastrin in the colon was also contradicted by the finding that longterm omeprazole treatment, although increasing gastrin concentrations, actually decreased the incidence of induced colon cancers in the rat. ${ }^{44}$ No significant effects on the colon were seen in this study despite the 'fasted' nature of the gut. Epidermal growth factor also stimulates gastrin transcription ${ }^{45}$ and is a powerful stimulator of gastrointestinal, and especially colonic growth. ${ }^{25} 46$ The results of this investigation would indicate that gastrin does not participate in modulating the trophic effects of epidermal growth factor.

In summary it can be concluded that gastrin and its synthetic analogue pentagastrin, promote cell proliferation in the fundus of the stomach, and in the proximal duodenum, but not throughout the small intestine. No proliferative effects were seen in the antrum of the stomach, or in the colon.

1 Preston-Martin S, Pike MC, Ross RK, Jones PA, Henderson BE. Increased cell division as a cause of human cancer. Cancer Res 1990; 50: 7415-21.

2 Wright NA, Alison MR. The biology of epithelial cell populations. Vol 2. Oxford: Oxford University Press, 1984

3 Willems G, Vansteenkiste Y, Limbosch JM. Stimulating effects of gastrin on cell proliferation kinetics in canine fundic mucosa. Gastroenterology 1972; 62: 583-9.

4 Walsh JH. Role of gastrin as a trophic hormone. Digestion 1990; 47: 11-6.

5 Carlsson E, Havu N, Mattsson H, Ekman L. Gastrin and gastric enterochromaffin-like cell carcinoids in the rat. Digestion 1990; 47: 17-23.
6 Tielemans Y, Hakanson R, Sundler F, Willems G. Proliferation of enterochromaffin like cells in omeprazoletreated hypergastrinemic rats. Gastroenterology 1989; 96: 723-9.

7 Eissele R, Rosskopf B, Koop H, Adler G, Arnold R Proliferation of endocrine cells in the rat stomach caused by drug-induced achlorhydria. Gastroenterology 1991; 101 $70-6$

8 Johnson LR. New Aspects of the trophic action of gastrointestinal hormones. Gastroenterology 1977: 72: 788-92.

9 Johnson LR. Regulation of gastrointestinal growth. In: ohnson LR, ed. Physiology of the digestive tract. New York: Raven Press, 1981: 169-96.

10 Mayston DD, Barrowman JA, Dowling RH. Effect of pentagastrin on small bowel structure and function in the rat. Digestion 1975; 12: 78-84.

11 Oscarson JEA, Veen HF, Williamson RCN, Chir B, Ross JS, Malt RA. Compensatory postresectional hyperplasia and starvation atrophy in small bowel: dissociation from and starvation atrophy in small bowel: dissociation from endoge

12 Hanson WR. Proliferative and morphological adaptation of the intestine to experimental resection. Scand $\mathcal{F}$ Gastroenterol 1982; 17: 11-20.

13 Al-Mukhtar MYT, Sagor GR, Ghatei MA, Polak JM, Kropmans HS, Bloom SR, et al. The relationship between endogenous GIT and cell proliferation in models of intestinal adaptation. In: Robinson JWL, Dowling RH, Reicken EO, ed. Mechanism of intestinal adaptation. Lancaster: MTP Press, 1982: 243-53.

14 Sagor GR, Ghatei MA, Al-Mukhtar MYT, Wright NA Bloom SR. Evidence for a humoral mechanism after intestinal resection, exclusion of gastrin but not enteroglucagon. Gastroenterology 1983; 54: 902-16.

15 Goodlad RA, A-Mukhtar MYT, Ghatei MA, Bloom SB Wright NA. Cell proliferation, plasma enteroglucagon and plasma gastrin in starved and refed rats. Virchows Archives B Cell Pathology 1983; 43: 55-62.

16 Goodlad RA, Wright NA. Quantitative studies on epithelia replacement in the gut. In: Titchen TA, ed. Techniques in the life sciences: techniques in digestive physiology. Shannon, Ireland: Elsevier Biomedical, 1982: 212/1-21.

17 Goodlad RA, Wright NA. Growth control factors in the gastrointestinal tract. Baillieres Clin Gastroenterol 1990; 4 $97-119$.

18 Chu M, Rehfeld JF, Borch K. Effects of gastric fundectomy and antrectomy on the colonic mucosa in the hamster. Digestion 1992; 53: 28-34.

19 Mak KM, Chang WWL. Pentagastrin stimulates epithelia cell proliferation in duodenal and colonic crypts in fasted rats. Gastroenterology 1976; 71: 1117-20.

20 Ahnen DJ, Bozdech J. Gastrin as a trophic hormone for the colon. In: Walsh JH, ed. Gastrin. New York: Raven Press, 1993: 301-6.

21 Eggstein S, Imadhl A, Kohler M, Waibel M, Farthman EH Influence of gastrin, gastrin receptor blockers, epidermal rowth factors and difluoromethylornithine on the orowth and activity of ornithine decarboxylase on gown carcinoma cells. F Cancer Res Clin Oncol 1991; 117: $37-42$.

22 Wong K, Beardsall K, Waters CM, Calam J, Poston GJ. Postprandial hypergastrinaemia in patients with colorectal Postprandial hypergastrinaemia in pat

23 Sobhani I, Lehy T, Laurent PP, Cadiot G, Ruszniewski P, Mignon M. Chronic endogenous hypergastrinaemia in humans: evidence for mitogenic effect on the colonic mucosa. Gastroenterology 1993; 105: 22-30.

24 Lloyd KCK, Walsh JH. Regulation of acid secretion in vivo. In: Walsh JH, ed. Gastrin. New York: Raven Press, 1993 $221-42$

25 Goodlad RA, Wilson TG, Lenton W, Wright NA, Gregory $\mathrm{H}$, McCullagh KG. Intravenous but not intragastric urogastrone-EGF is trophic to the intestinal epithelium of parenterally fed rats. Gut 1987; 28: 573-82.

26 Solomon TE. Trophic effects of pentagastrin on gastrointestinal tract in fed and fasted rats. Gastroenterology 1986; 91: 108-15.

27 Goodlad RA, Ghatei MA, Gregory H, Bloom SR, Wright NA. The effects of urogastrone-EGF on plasma hormone levels, a role for PYY? Experientia 1989; 45: 168-9.

28 Fatemi SH, Cullan GE, Sharp JG. Evaluation of the effects of pentagastrin, gastrin and pancreatic glucagon on cell proliferation in the rat gastrointestinal tract. Cell Tiss Kinet 1984; 17: 119-33.

29 Majumdar APN. Effects of fasting and refeeding on antral, duodenal and serum gastrin levels and on colonic thymidine kinase activity in rats. Hormone Res 1984; 19: 127-34.

30 Schwartz MA, Storozuk RB. Enhancement of small intestinal absorption by intra-luminal gastrin. Gastroenterology 1985; 88: 1587 .

31 Goodlad RA, Madgwick AJA, Moffatt MR, Levin S, Allen $\mathrm{JL}$, Wright NA. Prostaglandins and the gastric epithelium: effects of misoprostol on cell migration and transit in the dog stomach. Gastroenterology 1990; 96: 1-6.

32 Maurer HR. Potential pitfalls of 3H-thymidine technique to measure cell proliferation. Cell Tiss Kinet 1981; 14: 111-20.

33 Willems $\dot{G}$, Vansteenkiste $Y$. resistance of the antral mucosa to the trophic effect of gastrin in the dog. Biol Gastroenterol (Paris) 1974; 7: 237-40

34 Johnson LR. The trophic action of gastrointestinal hormones. Gastroenterology 1976; 70: 278-88.

35 Casteleyn PP, Dubrasquet M, Willems G. Opposite effects 
of gastrin on cell proliferation in the antrum and other parts of the upper gastrointestinal tract in the rat. Dig Dis 1977; 22: 798-804.

36 Hakanson R, Blom H, Carlsson E, Larsson H, Ryberg B, Sundler $\mathrm{F}$. Hypergastrinaemia produces trophic effects in stomach but not in pancreas and intestines. Regul Pept 1986; 13: 225-33.

37 Levi S, Goodlad RA, Lee CY, Stamp G, Walport MJ, Wright NA, et al. Inhibitory effect of non-steroidal anti-inflammatory drugs on mucosal cell proliferation associated with gastric ulcer healing. Lancet 1990; 336: 840-3.

38 Calam J. Gastrin release associated with Helicobacter pylori gastritis. In: Walsh JH, ed. Gastrin. New York: Raven gastritis. In: Walsh JH, ed. Gastrin. New York. Raven

39 Press, 1993: 335-48.

Winsett OE, Townsend CM, Glass EJ, Thompson JC. Gastrin stimulates the growth of colon cancer. Surgery 1985; 99: 302-7.

40 Watson S, Durrant L, Morris D. Gastrin: growth enhancing effects on human gastric and colonic tumour cells. $\mathrm{Br} \mathcal{F}$ Cancer 1989; 59: 554-8.

41 Lamote J, Willems G. Stimulating effect of pentagastrin on cancer cell proliferation kinetics in chemically induced colon cancer in rats. Regul Pept 1988; 20: $1-9$.

42 Tatsuta M, Yamamura H, Iishi $H$, Noguchi S, Ichii $M$ Tanguchi $H$. Gastrin has no promoting effect on chemically induced colonic tumours in Wistar rats. Eur $\mathcal{F}$ Cancer Clin Oncol 1985; 21: 741-4.

43 Finney KJ, Appleton DR, Ince P, Moorghen M, Elliott K, Watson AJ. Effects of gastrointestinal peptides on azoxymethane-treated colonic mucosa in vitro. Carcinogenesis 1991; 12: 2017-22.

44 Penman ID, El-Omar E, McGregor JR, Hillan KJ, O’Dwyer PJO, McColl KEL. Omeprazole inhibits colorectal carcinogenesis induced by axoymethane in rats. Gut 1993; 34: 1559-65.

45 Merchant JL, Demediuk B, Brand SJ. A GC-rich element confers epidermal growth factor responsiveness to transcription from the gastrin promoter. Mol Cell Biol 1991 11: 2686-96.

46 Goodlad RA, Wilson TG, Lenton W, Wright NA, Gregory $\mathrm{H}$, McCullagh KG. Urogastrone-epidermal growth facto is trophic to the intestinal epithelium of parenterally fed rats. Experientia 1985; 41: 1161-3. 